\title{
Usage of E-learning Tools in Self-education of Government Officers Involved in Global Trade Activities
}

\author{
Olga O. Triakina ${ }^{1 \text { [0000-0001-5872-3891] }}$ Olena O. Pavlenko ${ }^{1[0000-0002-3868-3252]}$, \\ Nataliia P. Volkova ${ }^{20000-0003-1258-7251]}$ and Darja A. Kassim ${ }^{2}$ \\ ${ }^{1}$ University of Customs and Finance, \\ 2/4, Volodymyra Vernadskoho St., Dnipro, 49000, Ukraine \\ ${ }^{2}$ Alfred Nobel University, 18, Naberezhna Sicheslavska St., Dnipro, 49000, Ukraine \\ ${ }^{3}$ Kryvyi Rih Metallurgical Institute of the National Metallurgical Academy of Ukraine, \\ 5, Stephana Tilhy St., Kryvyi Rih, 50006, Ukraine \\ o.triakina@ukr.net, amsu.pavlenko@gmail.com, npvolkova@yahoo.com
}

\begin{abstract}
The article concerns the issue of e-learning tools implementation, including the Customs Learning and Knowledge Community electronic platform designed by the World Customs Organization and the Trade Facilitation Implementation Guide case studies collected by the United Nations Economic Commission for Europe, into the self-education process of current government employees (within in-service training) and future public officers (within master's programs) connected with international trade transactions. The authors give a description of the content and characteristical features of existing e-learning instruments related to training of professionals in Customs and trade fields as well as of certain tasks developed by the authors. The efficiency of the abovementioned e-learning tools has been experimentally proved in the paper, which has shown that these tools promote the growth of the professional competence of government officers and give a great opportunity for them to be involved in life-long learning to acquire various professional knowledge and skills.
\end{abstract}

Keywords: e-learning tools, self-study, government officers, Customs Learning and Knowledge Community e-learning platform, case studies, interactive courses, self-education.

\section{Introduction}

Since out-of-date educational methods proved to be inefficient while informatization became a reality and systematically expands its influence, especially considering the global tendency of life-long learning [1;9], among the leading methods of organizing self-education activities of future professionals (individual search for professional information, use of modern information technologies, reflexive analysis of educational activities, self-compilation of results and forecasting) [14] the use of electronic training is considered to be an innovative method involving introduction of modern information technologies. So it has become a mainstream to devise various on-line techniques for electronic learning. Our study has revealed that the term "e-learning" in the works of 
scientists $[6 ; 8]$ is considered to be equal to the concepts of "distance learning, "online learning", "open education". Its main advantages are accessibility 24 hours a day, simplicity of usage as well as availability of various modern technologies.

Therefore, international organizations including the World Trade Organization (WTO), the European Union (EU), the World Customs Organization (WCO), the United Nations being concerned about government officers' level of professionalism, have developed specific electronic instruments for e-learning [4]. We are convinced that efficient electronic training of specialists worldwide and particularly in Ukraine is possible by means of these instruments adaptation to the national systems of professional training, in-service training and self-education.

\section{Description of the Existing E-learning Instruments Designed by the International Organizations for Self-education of International Trade-Related Government Employees}

In particular, the WCO electronic platform Customs Learning and Knowledge Community (CLiKC) [15] is designed for e-learning of Customs officers. This innovative electronic platform is fully consistent with the objectives of training a highly qualified customs officer, namely: facilitates the development of professional knowledge of Customs officers, provides modern structures and methods of effective professional training in the field of Customs, promotes the improvement of scientific research as well as provides ideas for the adaptation of in-service training models under the demands of national Customs administrations. These goals are clearly reflected in its structure, consisting of the following three elements:

1. educational materials (electronic thematic modules; interactive training courses; regulatory documents including the main Customs and trade standards and procedures of international organizations; demo slides; glossaries; instructions on portfolio drawing);

2. methods of professional knowledge assessment (intermediate tests, exercises, surveys and tasks for monitoring the level of knowledge at a particular topic);

3. tools of interaction (forums, chats, expert pools, blogs, workshops). These tools facilitate the exchange of experience concerning the implementation of the WCO CLiKC e-learning platform into national Customs training programs as well as provide an opportunity to discuss the problematic issues that arise in the professional activities of Customs officers [7].

The thematic modules (see table 1) [15] were presented in the form of lectures with a defined content, step by step elaborated curriculum and practical tasks for solving certain professional situations. They cover issues of the Revised Kyoto Convention, risk assessment, profiling and selection of passengers and cargoes for inspection, Customs valuation as well as commercial fraud questions.

Interactive training courses, in turn, contain relevant theoretical material, aimed at deepening the knowledge system, creation of professional skills and abilities, including 
professionally-oriented tasks of various levels of complexity, which encourage students' creative activity, analytical approach to the solution of professional problems. For learners' comfort they are included in four thematic blocks (see table 2) [15] and are available in five languages: English, French, Arabic, Spanish, Portuguese and Russian. In our opinion, such structure of the electronic platform for Customs training contributes to the successful performance of learners' self-study, since it involves a high level of motivation, clear statement of cognitive tasks, understanding of the algorithm and methods of performing self-study assignments, types and forms of control and evaluation criteria [5].

Table 1. Example of thematic modules included into CLiKC

\begin{tabular}{|l|l|}
\hline Thematic module (hours) & \multicolumn{1}{|c|}{ Topics for practical training } \\
\hline $\begin{array}{l}\text { 1. Revised Kyoto Conven- } \\
\text { tion (8) }\end{array}$ & $\begin{array}{l}\text { Lesson 1. Reasons for revision of the International Con- } \\
\text { vention on the Simplification and Harmonization of } \\
\text { Customs Procedures } \\
\text { Lesson 2. The structure of the Revised Kyoto Conven- } \\
\text { tion } \\
\text { Lesson 3. General Appendix } \\
\text { Lesson 4. Special Appendixes }\end{array}$ \\
\hline $\begin{array}{l}\text { 2. Risk assessment, profiling } \\
\text { and selection of passengers } \\
\text { and cargoes for inspection } \\
\text { (42) }\end{array}$ & $\begin{array}{l}\text { Lesson 1. Risk assessment: concepts } \\
\text { Lesson 3. Pisk management cycle } \\
\text { Lesson 4. Public and private flights } \\
\text { Lesson 5. Commercial airplanes } \\
\text { Lesson 6. Profiling of passengers } \\
\text { Lesson 7. Passenger selection for inspection } \\
\text { Lesson 8. Smuggling of drugs by intracorporal methods } \\
\text { Lesson 9. Checking passports } \\
\text { Lesson 10. Checking airline tickets } \\
\text { Lesson 11. Profiling and selection of commercial car- } \\
\text { goes for inspection } \\
\text { Lesson 12. Air cargo risk indicators } \\
\text { Lesson 13. Smuggling } \\
\text { Lesson 14. Ships selection for search } \\
\text { Lesson 15. Risk indicators for marine cargo } \\
\text { Lesson 16. Smuggling through land borders } \\
\text { Lesson 17. Way of thinking of traffickers } \\
\text { Lesson 18. Post-seizure analysis } \\
\text { Lesson 19. Operational activities } \\
\text { Lesson 20. Memorandum of Understanding }\end{array}$ \\
\hline
\end{tabular}

Our study has found out that the mentioned interactive courses include innovative learning tools that help future Customs officers (within the framework of master's programs) or current employees of Customs administrations (within the framework of in-service training programs) acquire necessary skills to solve professional tasks, act operatively 
in specific situations and process information flows. In addition, the content of the training materials included ultimately corresponds to demands for the professional training of highly skilled specialists. In particular, situational tasks, business and role games, problem issues, slides and video materials, case studies based on international agreements and conventions effectively reflect the trends of the international Customs environment and promote a consistent and systematic development of both professional, organizational, managerial and communicative competences of Customs and other trade-related government officers within the self-study process [6, pp. 189-193; 10].

Table 2. Interactive training courses of the WCO electronic platform CLiKC (250 hours)

\begin{tabular}{|c|c|c|c|}
\hline $\begin{array}{c}\text { Block } 1 \\
\text { Law enforcement activi- } \\
\text { ties }\end{array}$ & $\begin{array}{c}\text { Block } 2 \\
\text { Conventions and docu- } \\
\text { ments }\end{array}$ & $\begin{array}{c}\text { Block } 3 \\
\text { Tariffs and trade }\end{array}$ & \begin{tabular}{|c|} 
Block 4 \\
Capacity \\
building of \\
Customs ad- \\
ministrations
\end{tabular} \\
\hline $\begin{array}{l}\text { - Customs control } \\
\text { - Protection of intellectual } \\
\text { property rights } \\
\text { - Post-audit } \\
\text { - Multilateral agreements } \\
\text { on the protection of the } \\
\text { environment } \\
\text { - Convention on Interna- } \\
\text { tional Trade in Endan- } \\
\text { gered Species of Wild } \\
\text { Fauna and Flora (CITES) } \\
\text { - Substances that destroy } \\
\text { the ozone layer } \\
\text { - Risk assessment } \\
\text { - Commercial fraud }\end{array}$ & $\begin{array}{l}\text { - TIR Convention } \\
\text { - Framework Standards } \\
\text { for Security and Simpli- } \\
\text { fication of International } \\
\text { Trade Procedures } \\
\text { - Convention on Tem- } \\
\text { porary Importation } \\
\text { - WCO Data Model } \\
\text { - Revised Kyoto Con- } \\
\text { vention }\end{array}$ & $\begin{array}{l}\text { - Harmonized } \\
\text { commodity de- } \\
\text { scription and } \\
\text { coding system } \\
\text { - Customs valua- } \\
\text { tion } \\
\text { - Transfer prices } \\
\text { - Rules of origin }\end{array}$ & $\begin{array}{l}\text { - Integrity of } \\
\text { Customs of- } \\
\text { ficers }\end{array}$ \\
\hline
\end{tabular}

Another example of using e-learning instruments for training both government officers and business sector employees involved in international trade operations is related to Trade Facilitation Implementation Guide (TFIG) designed by the United Nations Economic Commission for Europe [13] and the EU Customs Competency Framework [2]. TFIG covers different case studies and best practices including such issues as Single Window, Authorized Economic Operator, advance rulings, post-clearance audit etc. that can be used as topics for on-line discussions, debates, presentations, comparative analysis, brainstorming and other forms of interactive learning, while the Customs Competency Framework describes key requirements for Customs profession and practical techniques to achieve necessary Customs knowledge and skills. 


\section{Implementation of the E-learning Tools into the Professional Training of Government Officers Related to International Trade Activities}

Implementation of the WCO CliKC electronic platform and e-learning instruments of other international organizations was made, primarily, in the educational process of masters in the field of Customs. The following steps were taken: registration of students in the system using passwords received from the national coordinator; students' work with materials covering thematic modules and interactive courses as well as TFIG case studies, tasks, exercises, scenarios; studying into authentic English texts, compiling vocabularies, searching for additional materials in a foreign language, expanding the understanding of the main professional categories, discussing situations in professional English with the use of different grammatical and lexical constructions, scenario modeling through role-playing and business games (among others, within classes of "Business English" and "Foreign language for professional purposes"); fulfillment of tasks being developed by authors on the base of the mentioned e-learning instruments for online discussions and forums (see table 3 containing several examples of such tasks) [12, pp. 176-185]. All of these contributed to the development of both professional knowledge and skills as well as the improvement of professionally-directed foreign language communicative competence of future government officers.

Table 3. Tasks for on-line discussions

\begin{tabular}{|c|c|c|}
\hline $\begin{array}{l}\text { Thematic } \\
\text { module / } \\
\text { Interac- } \\
\text { tive course }\end{array}$ & Questions for discussion & Situations for discussion \\
\hline $\begin{array}{l}\text { 1. Risk as- } \\
\text { sessment }\end{array}$ & $\begin{array}{l}\text { 1. How can term "risk" be under- } \\
\text { stood from a Customs viewpoint? } \\
\text { 2. Which businesses does risk as- } \\
\text { sessment cover and in which way? } \\
\text { Give certain examples } \\
\text { 3. Which risk areas does import or } \\
\text { export of commercial consign- } \\
\text { ments include? }\end{array}$ & $\begin{array}{l}\text { At Frankfurt airport, German Cus- } \\
\text { toms seized } 10 \text { kgs of cocaine from a } \\
\text { shipment of automobile parts from } \\
\text { Brazil. On examining their date base, } \\
\text { Customs officers found that this was } \\
\text { the seventh case in two years involv- } \\
\text { ing automobile parts shipped from } \\
\text { Brazil. }\end{array}$ \\
\hline $\begin{array}{l}\text { 2. Security } \\
\text { of supply } \\
\text { chain }\end{array}$ & $\begin{array}{l}\text { 1. What is a bill of lading? In } \\
\text { which situations is it used? } \\
\text { 2. What is a bill of exchange? } \\
\text { Which main steps need to be taken } \\
\text { to make a bill of exchange pay- } \\
\text { ment? } \\
\text { 3. What is a letter of credit? What } \\
\text { does it guarantee? } \\
\text { 4. Which other terms of delivery } \\
\text { are used in the international trade } \\
\text { transactions? Give some examples. }\end{array}$ & $\begin{array}{l}\text { On the arrival of a flight from Bogota } \\
\text { (Colombia), the Customs Targeting } \\
\text { Unit at Paris international airport } \\
\text { picked out an air waybill for a ship- } \\
\text { ment of handicrafts bound for France. } \\
\text { The company shown as consignor was } \\
\text { unknown, and the company shown as } \\
\text { consignee was not listed under the ad- } \\
\text { dress given. The telephone number } \\
\text { was a real one, but it was a number of } \\
\text { a bookshop whereas it should have }\end{array}$ \\
\hline
\end{tabular}




\begin{tabular}{|c|c|c|}
\hline $\begin{array}{c}\text { Thematic } \\
\text { module / } \\
\text { Interac- } \\
\text { tive course }\end{array}$ & \multicolumn{1}{|c|}{ Questions for discussion } & \multicolumn{1}{c|}{ Situations for discussion } \\
\hline & $\begin{array}{l}\text { 5. What are potential risks of fraud } \\
\text { in the flow of goods in interna- } \\
\text { tional trade? } \\
\text { 6. What steps should be taken to } \\
\text { secure international flow of goods? }\end{array}$ & $\begin{array}{l}\text { been arts and crafts shop. An exter- } \\
\text { no markings on the packages. When } \\
\text { the pages were opened, they were } \\
\text { found to contain handicrafts made } \\
\text { from cocaine paste. There were } 20 \mathrm{kgs} \\
\text { of cocaine. }\end{array}$ \\
\hline
\end{tabular}

The tasks developed by the authors were also tested and then introduced into the system of training personnel of the Customs authorities of Ukraine. In particular, Khmelnytsky Customs Human Resources department was offered to use the theoretical points and practical recommendations for implementation of the e-learning platform CLiKC in the process of self-education of Customs officers as well as the methodical provision, namely the textbook developed by the author [11] for professional competence improvement.

Thus, after organizing and conducting the experimental training, which took place under the influence of specially developed pedagogical technology, we conducted a diagnosis of the level of Customs officers' professional competence development in the control (CG) and two experimental groups (EG1 and EG20). Data obtained during this process were mathematically and statistically processed using Pearson's $\chi^{2}$ and Fischer criteria [15]. The obtained results are summarized in table 3 and the following diagram (see Fig. 1), the analysis of which enables to trace the growth of the phenomenon being researched [12, pp. 190-193].

Table 4. General assessment of the levels of professional competence development

\begin{tabular}{|c|c|c|c|c|c|c|c|c|c|c|c|c|}
\hline \multirow{3}{*}{ Level } & \multicolumn{6}{|c|}{ Diagnostic phase } & \multicolumn{6}{|c|}{ Control phase } \\
\hline & \multicolumn{2}{|c|}{ CG } & \multicolumn{2}{|c|}{ EG1 } & \multicolumn{2}{|c|}{ EG2 } & \multicolumn{2}{|c|}{ CG } & \multicolumn{2}{|c|}{ EG1 } & \multicolumn{2}{|c|}{ EG2 } \\
\hline & $\mathbf{N}$ & $\%$ & $\mathbf{N}$ & $\%$ & $\mathbf{N}$ & $\%$ & $\mathbf{N}$ & $\%$ & $\mathbf{N}$ & $\%$ & $\mathbf{N}$ & $\%$ \\
\hline & 9 & 12,86 & 12 & 14,12 & 10 & 13,33 & 12 & 17,1 & 40 & 54,12 & 35 & 46,67 \\
\hline Mediu & 19 & 27,14 & 26 & 30,59 & 22 & 29,33 & 22 & 31,4 & 36 & 42,35 & 31 & 41,33 \\
\hline Low & 42 & 60,00 & 47 & 55,29 & 43 & 57,3 & 36 & 51,4 & 3 & 3,53 & 9 & 12,00 \\
\hline
\end{tabular}

Consequently, the figures obtained show significant changes in the two experimental groups in comparison with the results acquired during the diagnostic phase. As it can be seen, $54.12 \%$ respondents of the first experimental and $46.67 \%$ respondents of the second experimental group reached a high level of knowledge, mastery of necessary skills and development of professionally significant personal qualities. In the control group, which was trained according to a standardized scheme, the high level of professional competence increased only by $4.28 \%$, while the indicator of the same level in the first experimental group rose by $40 \%$, in the second experimental group - by $33.34 \%$. 


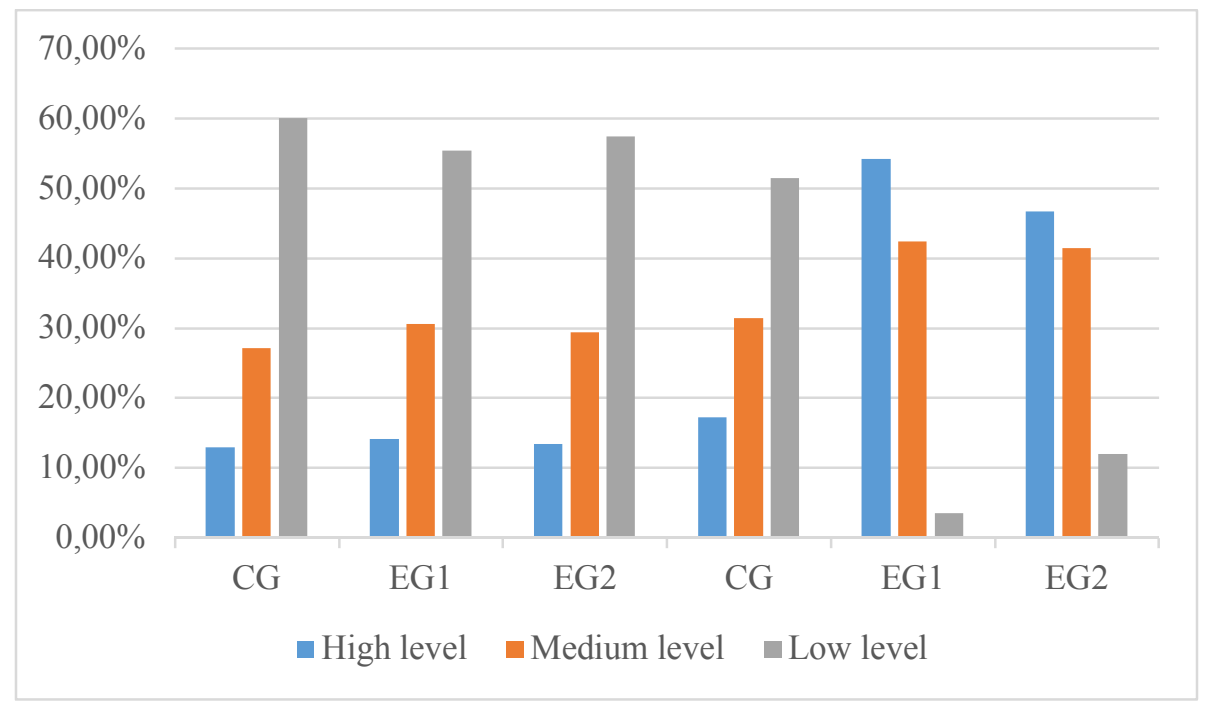

Fig. 1. Comparative diagram of evaluation of the professional competence improvement at the diagnostic and control stages of the experiment

In our opinion, such results were achieved due to the updating of the content of the specialized training by means of implementing the CLiKC e-learning platform, other e-learning instruments as well as specific tasks developed by the authors into the framework of self-study process of current and future staff of the Ukrainian Customs and other trade-related government authorities.

\section{Conclusions}

To sum it up, we should highlight that the abovementioned e-learning instruments are the most progressive methods of training current and future government employees connected with global trade operations, since they have many opportunities and benefits, namely:

- stipulate tutoring, facilitate access to Customs and trade experience (TFIG case studies), current legal and regulatory framework;

- include a variety of relevant theoretical and practical teaching materials, the content of which promotes learners' cognitive activity, since it reflects current conditions of Customs environment worldwide and provides specific tools for solving professional problems;

- the content of interactive courses of the CliKC e-learning platform simulates the future professional activity of a specialist;

- tasks, exercises and scenarios have video and audio support that stimulate interest and motivation of students; 
- the diversity of authentic texts and professional vocabulary in foreign languages accompanied by audio and video files leads to the improvement of professionally-oriented foreign language communicative competence;

- electronic training modules facilitate consistent and systematic acquisition of professional knowledge and skills in accordance with the international professional standards of Customs and other government officers;

- include automatic assessment systems for evaluation of achievements within each interactive course that stimulates self-esteem and self-reflection;

- offer government agencies and business structures an opportunity to share documents and experiences concerning managerial, strategic and technical issues;

- they are an effective tool for developing the competences of future specialists in the field of foreign economic activity;

- provide life-long professional improvement.

\section{References}

1. European Comission: Explaining the European Qualifications Framework for Lifelong Learning. Office for Official Publications of the European Communities, Luxembourg (2008)

2. European Commission: EU Customs Competency Framework. https://ec.europa.eu/taxation_customs/eu-training/eu-customs-competency-framework_en (2016). Accessed 25 Dec $201 \overline{7}$

3. Fisher, R.A.: Statistical Methods For Research Workers. Oliver and Boyd, Edinburgh (1925)

4. Graaf, M.: Communication, integral to the achievements of the European Union Customs Union. WCO News. 73, 24-25 (2014)

5. Pavlenko, O.O., Triakina, O. O., Timchenko-Mikhailidi, N.S., Pugach, V.B.: Evaluation of the communicative competence level of masters in the field of foreign economic activity and methods of its development. Bulletin of Alfred Nobel University, Series "Pedagogy and Psychology". 2(14), 197-203 (2017)

6. Pavlenko, O.O.: Formuvannia komunikatyvnoi kompetentsii fakhivtsiv mytnoi sluzhby v systemi neperervnoi profesiinoi osvity (Forming Communicative Competency of Customs Officers under the System of Lifelong Professional Education). Dissertation, Taras Shevchenko National University of Kyiv (2010)

7. Poro, A.: European Customs training community benefits from new knowledge sharing tool. WCO News. 64, 32-33 (2011)

8. Semerikov, S.O., Striuk, M.I., Moiseienko, N.V.: Mobilne navchannia: istoryko-tekhnolohichnyi vymir (Mobile learning: historical and technological dimension). In: Konoval, O.A. (ed.) Teoriia i praktyka orhanizatsii samostiinoi roboty studentiv vyshchykh navchalnykh zakladiv (Theory and practice of organization of independent work of students of higher educational institutions), pp. 188-242. Knyzhkove vydavnytstvo Kyreievskoho, Kryvyi Rih (2012)

9. Striuk, M.I., Semerikov, S.O., Striuk, A.M.: Mobilnist: systemnyi pidkhid (Mobility: a systems approach). Information Technologies and Learning Tools. 49(5), 37-70 (2015)

10. Triakina, O.A.: Implementation of the on-line modules of the World Customs Organization into professional training of Ukrainian Customs personnel. Europaische Fachhochschule, 6, 31-33 (2014) 
11. Triakina, O.O., Movchan, D.O.: Foreign language for professional purposes (English): manual for students' self-study. AMSU, Dnipropetrovsk (2014)

12. Triakina, O.O.: Pidhotovka mahistriv u haluzi mytnoyi spravy na zasadakh mizhnarodnykh profesiynykh standartiv mytnykiv (Training of masters in the field of Customs affairs in accordance with the international Professional Standards of Customs officers). Dissertation, Classical private university (2015)

13. UNECE: Trade Facilitation Implementation Guide. http://tfig.unece.org (2012). Accessed 25 Dec 2017

14. Volkova, N.P., Tarnopolskyi, O.B.: Modeliuvannia profesiinoi diialnosti u vykladanni navchalnykh dystsyplin u vyshakh (Modeling of professional activity in teaching of academic disciplines in higher education). Alfred Nobel University, Dnipropetrovs'k (2013)

15. World Customs Organization. http://www.wcoomd.org (2018). Accessed 27 Jan 2018 